\title{
PENGEMBANGAN ANTIBODI POLIKLONAL DARI STADIUM TAKIZOIT TOXOPLASMA GONDII ISOLAT WTA
}

\author{
Purwaningtyas Kusumaningsih \\ Program Studi Ilmu Gizi Universitas Dhyana Pura \\ Email: purwak.05@undhirabali.ac.id
}

\begin{abstract}
ABSTRAK
Antibody poliklonal sebagai sumber dasar skrining antigen yang dihasilkan melalui teknik kloning gen penyandi protein escretory surface antigen (ESA) Toxoplasma gondii. Skrining diperlukan untuk mengetahui reaksi imunitas protein rekombinan ESA yang mampu mengenali protein anti-ESA secara biomolekuler dan spesifik. Penelitian ini bertujuan untuk menghasilkan antibodi poliklonal untuk digunakan dalam pengembangan teknik analisa Western-blot. Antigen yang digunakan berasal dari crude protein ESA, dari stadium takizoit. Mencit BALB/c betina berumur 8-10 minggu disuntik crude protein ESA pada rongga peritoneum mencit. Penyuntikan ulang (booster) diulang sebanyak 5 kali dengan interval waktu 14 hari. Serum dari mencit dikoleksi dan diukur titernya dengan ELISA, dan dilanjutkan pada analisa Western-blot. Hasil analisis Western-blot menunjukkan bahwa antibodi poliklonal yang dikembangkan pada mencit mampu bereaksi secara spesifik terhadap antigen yang dihasilkan melalui rekayasa genetik. Berdasarkan hal ini dapat disimpulkan bahwa antibodi poliklonal yang dikembangkan pada mencit telah berhasil dan dapat digunakan sebagai reagen immunoproteomik.
\end{abstract}

Kata Kunci : antibody poliklonal, analisa Western-blot, Toxoplasma gondii.

\begin{abstract}
Polyclonal antibody is a basic resource in screening antigen from recombinant DNA technology of excretory surface antigen of Toxoplasma gondii. Screening is using to analyze the immunity reaction of recombinant protein to recognize the antibody in specific and molecular. The aim of this research is to produce excretory surface antigen (ESA) of Toxoplasmaa gondii and can developed for Western-blot analyze. The antigen is from cruse protein isolated tachyzote of Toxoplasma gondii. Female mice are in age 8-10 weeks, injected in the peritoneum. The booster is injected for five times, in interval every 14 days. The serums are collected and analyze by ELISA and use it on Western-blot. The result is the polyclonal antibody showed reaction with the antigen from genetic engineering. From this result it can concluded that the developing of this antibody is successful and it can be used as an immunoproteomic reagent.
\end{abstract}

Keyword: Polyclonal antibody, Western-blot, Toxoplasma gondi

\section{PENDAHULUAN}

Toksoplasmosis pada hewan ternak seperti kambing, domba, sapi, babi dan unggas lebih difokuskan imbasnya kepada permasalahan ekonomi. Toksoplasmosis pada ternak dapat mengakibatkan kongenital toksoplasmosis sehingga dapat menyebabkan cacat fisik, aborsi dan kematian fetus. Kondisi ini akan mempengaruhi penyediaan bibit unggul hewan ternak. Bukan hanya itu saja, terbentuknya kista jaringan pada daging hewan ternak yang terinfeksi T. Gondii dapat mengurangi kualitas daging serta merupakan sumber infeksi apabila dikonsumsi manusia. Kondisi ini jelas akan mengurangi pemenuhan kebutuhan pangan manusia, khususnya penyediaan daging dengan kualitas baik, sehat dan aman untuk dikonsumsi (Dubey, 2007).

Kemampuan $\mathrm{T}$. gondii secara aktif melakukan invasi ke dalam sel inang, merupakan faktor penentu mengapa $T$. gondii dapat menginfeksi berbagai macam sel berinti. Protein yang berkaitan langsung dalam invasi ke sel inang adalah protein yang disekresikan pada permukaan parasit (surface antigen/SAG) dan protein beredar (excretorysecretory antigen/ESA) (Black and Boothroyd, 2000; Schwartzman, 2001).

Protein SAG berperan dalam melakukan kontak langsung dengan permukaan sel inang (attachment). Protein SAG diketahui ada lima jenis SAG-1, p35 (SAG-1 family), SAG-2, p23(SAG-2 family) dan SAG-3. Surface antigen 1 yang paling banyak disekresikan selama proses perlekatan, dan dapat dideteksi pada fase takizoit (Liu et al., 2006).

Protein ESA berperan pada proses penetrasi dan pembentukan vakuola parasitoporus. Toxoplasma gondii mempunyai tiga organela sekresi, yaitu micronemes, rophtry dan dense granule. Ketiga organel tersebut memproduksi protein ESA, protein Micronemes (MIC) dan protein Rophtry (ROP) yang disekresikan parasit, sedangkan protein Dense granule (GRA) disekresikan dibagian belakang dan sisi sel parasit. 
Pada tahap awal penetrasi micronemes melepaskan protein MIC yang bersifat adhesin untuk mengadakan perlekatan dengan reseptor sel inang. Beberapa detik kemudian protein ROP disekresikan untuk membentuk vakuola parasitoporus. Pada tahap akhir, setelah proses invasi selesai protein GRA disekresikan secara bertahap ke dalam vakuola parasithophorus. Kerja sama ketiga komponen protein ESA bertujuan untuk memenuhi kebutuhan metabolisme parasit yang diambil dari sitoplasma dan organel sel inang (Carruthers, 2004; Templeton, 2007).

Roberts et al. (2007), melaporkan bahwa interaksi yang terjadi antara antigen $T$. gondii dengan sel inang dapat menimbulkan respon imun berupa sekresi sitokin seperti IL-12, IFN- $\gamma$, TNF- $\alpha$ dan reaksi nitrogen intermediat (RNI) oleh tubuh inang sebagai mediator sistem kekebalan tubuh inang dari serangan $T$. gondii. Sel T CD4+ dan $\mathrm{CD} 8+$ termasuk komponen penting kekebalan tubuh inang terhadap infeksi $T$. gondii. Setelah terjadi infeksi oosit di dalam tubuh inang perantara, maka takizoit akan dilepaskan untuk memulai proses replikasi intraseluler. Apabila tidak segera dikendalikan oleh sistem imun, takizoit merupakan fase virulen dan menyebabkan toksoplasmosis akut. Oleh karena itu, induksi respon imun sel $\mathrm{T}$ dalam melawan invasi takizoit memegang kunci keberhasilan memotong jalur hidup $T$. gondii, apakah tubuh inang mampu mengatasi invasi $T$. gondii dan mengeliminasi $T$. gondii dari tubuh atau parasit mampu menghindar dari sistem imun (Denkers and Gazzinelli, 1998).

Beberapa tahun belakangan ini banyak dilakukan penelitian-penelitian tentang protein SAG dan ESA T. gondii untuk dikembangkan sebagai agen diagnostik penyakit toksoplasmosis dan kandidat vaksin. Penyediaan protein rekombinan $T$. gondii diproduksi menggunakan metode rekayasa genetik yaitu kloning gen, sehingga dapat memproduksi protein dalam jumlah besar untuk menekan biaya pembuatan vaksin dan pengadaan protein sebagai perangkat diagnostik (Wong, 2006).

Penggunaan kombinasi tiga antigen rekombinan SAG-1, GRA-1 dan GRA-7 oleh Pietkiewicz et al. (2004), diketahui dapat meningkatkan sensitivitas pada ELISA. Pengembangan antigen rekombinan SAG-1 dan GRA-1 yang dikombinasi dengan adjuvant untuk dijadikan vaksin dilaporkan memberikan hasil yang maksimal dalam meningkatkan respon imun serta mampu mencegah penularan $T$. gondii secara kongenital (Bivas-benita et al., 2003; Couper et al., 2003).

Antibodi poliklonal T. gondii isolat WTA yang diperoleh dengan menyuntikkan crude protein soluble takizoit (ESA) T. gondii pada mencit akan diujikan pada protein rekombinan (antigen) hasil kloning gen penyandi protein ESA T. gondii. Metode yang digunakan untuk mengetahui reaksi imunogenik antara antigen dengan antibody adalah analisis Western-blot. Western-blot merupakan metode identifikasi untuk memberikan konfirmasi lebih akurat hasil ekspresi protein rekombinan. Setelah protein dipisahkan dengan PAGE, protein ditransfer ke atas permukaan kertas nitroselulose dibatasi dengan kertas filter, diperantarai dengan buffer elektroda dan dialiri listrik. Antibodi spesifik hanya akan terikat pada epitop protein rekombinan yang dikenali. Hasil pita yang bereaksi harus sesuai dengan berat molekul protein yang diprediksi (Janeway, 2001).

Hasil penelitian ini diharapkan untuk dapat mempelajari karakteristik dan imunogenitas antara antibodi poliklonal protein ESA $T$. gondii dengan antigen rekombinan, sehingga kedepannya dapat dikembangkan sebagai perangkat diagnostik dan kandidat vaksin protein rekombinan.

\section{METODE}

\section{Produksi Antibodi Poliklonal anti-ESA \\ Penghitungan konsentrasi protein ESA}

Konsentrasi yang diisolasi dari takizoit, diukur dengan cara mencampur $2 \mu$ l protein dengan $200 \mu 1$ BPA (Biorad Protein Assay) dan $789 \mu 1$ H2O, kemudian diukur optical density (OD) dengan spektrofotometer dengan panjang gelombang 595 $\mathrm{nm}$.

\section{Imunisasi mencit BALB/c}

Crude protein soluble takizoit (ESA) $T$. gondii sebanyak $5 \mu \mathrm{g} / \mu \mathrm{l}$ dilarutkan dalam aquabidest steril dan diemulsikan dengan freund's complete adjuvant (perbandingan 1:1) untuk penyuntikkan pertama, sedangkan untuk penyuntikkan kedua dan seterusnya digunakan incomplete adjuvant. Emulsi disuntikkan pada rongga peritoneum mencit $\mathrm{BALB} / \mathrm{c}$ betina berumur 8-10 minggu dengan jarum 25 G. Penyuntikan ulang (booster) diulang sebanyak 5 kali dengan interval waktu 14 hari.

\section{Pemisahan serum (antibodi poliklonal anti- ESA)}

Pengambilan serum dilakukan untuk menentukan titer antibodi dan untuk mengetahui respon imun mencit $\mathrm{BALB} / \mathrm{c}$ yang dilakukan satu pekan setelah imunisasi terakhir. Cuplikan sampel darah diambil melalui bagian ujung orbital mata dengan menggunakan tabung microhematockrit. Pengambilan cuplikan darah dapat dilakukan kembali 2 pekan berikutnya. Darah yang terambil didiamkan 30 menit pada temperatur $4^{\circ} \mathrm{C}$ supaya serum terpisah dari eritrosit yang menggumpal 
(darah dapat disimpan di freezer jika tidak langsung dilakukan pengujian). Serum yang telah terpisah disentrifugasi dengan kecepatan $3.000 \mathrm{rpm}$ pada temperatur ruang selama 30 menit untuk menghilangkan gumpalan darah. Serum diambil, dimasukan ke dalam microtube $1,5 \mathrm{ml}$ dan disimpan pada temperatur $-20^{\circ} \mathrm{C}$.

\section{Penentuan titer antibody}

Penentuan titer antibodi serum mencit yang telah diimunisasi dilakukan dengan metode ELISA. Setiap sumuran plat mikro (plastic microtiter plate) dilapisi dengan protein soluble ESA $T$. gondii dengan konsentrasi $5 \mu \mathrm{g} / \mathrm{ml}$ dalam $100 \mu \mathrm{l}$ coating buffer yang terdiri dari solution A dan solution $\mathrm{B}$, kemudian diinkubasi pada waterbath $37^{\circ} \mathrm{C}$ selama semalam. Plat mikro kemudian dicuci $3 \mathrm{X}$ dengan washing solution dan ditambah blocking buffer, setelah itu diinkubasi selama 1 jam pada temperatur $37^{\circ} \mathrm{C}$ lalu dicuci dengan washing solution. Setiap sumuran ditambah $100 \mu \mathrm{l}$ serum (antibodi poliklonal anti-ESA) mencit dengan tingkat pengenceran $(1: 50,1: 100,1: 200,1$ : $400,1: 800,1: 1600,1: 3.200,1: 6.400)$ dan kemudian diinkubasi selama 1 jam pada temperatur $37^{\circ} \mathrm{C}$. Plat mikro kemudian dicuci dengan washing solution sebanyak 3 kali, dan tambahkan $100 \mu \mathrm{l}$ konjugat (antimouse IgG alkaline phospatase) diencerkan dalam buffer inkubasi dengan perbandingan $1: 3000$. Plat mikro diinkubasi lagi selama 1 jam pada temperatur $37^{\circ} \mathrm{C}$. Plat mikro yang telah diinkubasi, dicuci 3 kali dengan washing solution. Pada masing-masing sumuran ditambahkan $150 \mu \mathrm{l}$ substrat dan diinkubasi 30 menit pada temperatur $37^{\circ} \mathrm{C}$. Titer antibodi setelah diinkubasi 15 menit dan 30 menit dibaca nilai serapannya pada Elisa Reader (TitertekÒMultiskan MCC/340, Labsystems) pada OD450 nm. Kontrol negatif berupa buffer inkubasi sebagai pengganti antibodi. Hasil positif bila nilai OD 3 kali kontrol negatif. Analisa menggunakan ELISA dapat mengetahui antibodi mana yang paling tinggi titernya dimana antibodi tersebut akan digunakan untuk immunobloting.

\section{Immunobloting}

Holzel blotter dibasahi dengan buffer bloting, dan dilapisi dengan kertas whatman sebanyak 4 lembar yang telah dibasahi dengan buffer bloting. Membran nitroselulose yang telah dibasahi dengan buffer bloting diletakkan pada tumpukan kertas Whatman. Gel poliakrilamid dari elektroforesis dengan SDS-PAGE diletakkan di atas membran nitroselulose, dan diberi penanda dengan jarum 20 gauge sebagai tempat orientasi letak sampel. Gel kemudian ditutup dengan kertas Whatman 4 lapis yang telah dibasahi dengan buffer bloting. Blotter ditutup dengan penutup blotter. Transfer protein dilakukan pada red current menunjukkan angka 500, selama 1-2 jam. Membran nitroselulose diambil dan dibloking dengan BSA $1 \%$, dan diinkubasi selama 1 jam dengan sheker pada temperatur kamar. Bovine Serum Albumin (BSA) $1 \%$ dibuang dan antibodi poliklonal mencit terhadap ESA T. gondii isolat WTA dicampur dengan larutan buffer inkubasi dengan perbandingan (1:200) ditambahkan dan diinkubasi selama 1 jam dengan agitasi pada temperatur kamar. Antibodi dibuang dan membran nitroselulose dicuci sebanyak 5 kali dengan TBS Tween $0,05 \%$ dengan masing-masing pencucian diagitasi selama 10 menit. Membran nitoselulose Dicelupkan ke dalam IgG goat anti mouse (whole molecule) alkaline phosphatase conjugated dengan (1:3000), dan diinkubasi selama 1 jam pada temperatur kamar dengan agitasi. Pencucian dilakukan 5 kali dengan TBS Tween $0,05 \%$, masing-masing pencucian selama 10 menit dengan agitasi. Pencucian terakhir hanya menggunakan TBS pH 7,5 tanpa Tween 20. Membran nitroselulose dicelup ke dalam larutan substrat nitro blue tetrazolium (NBT) dan 5-bromo-4-chloro-3indolyl-phosphate (BCIP) diruang gelap. Reaksi dihentikan dengan memasukkan membran nitroselulose ke dalam akuades, apabila sudah terjadi pembentukan warna. Membran kemudian dikeringkan pada temperatur kamar dan dianalisa.

\section{HASIL DAN PEMBAHASAN Produksi Antibodi Poliklonal anti-ESA T. gondii}

Protein ESA yang diperoleh dari hasil isolasi protein ESA takizoit $T$. gondii, digunakan untuk memproduksi antibodi poliklonal anti-ESA. Protein ESA diimunisasikan ke mencit $\mathrm{BALB} / \mathrm{c}$ berjenis kelamin betina. Pengambilan serum mencit yang mengandung antibodi poliklonal dilanjutkan dengan pengukuran kadar antibodi menggunakan metode ELISA.

\section{ELISA}

Nilai kadar antibodi poliklonal anti-ESA ditentukan dari hasil pembacaan ELISA reader dengan panjang gelombang $405 \mathrm{~nm}$.

Pengujian ELISA mempergunakan antigen ESA sebagai pelapis dasar sumuran (coating), kemudian ditambahkan antibodi anti-ESA yang berasal dari serum mencit hasil imunisasi sebagai antibodi primer atau antibodi poliklonal anti-ESA yang akan diukur. Sehingga akan terbentuk ikatan komplek antara antigen-antibodi, yang tidak berikatan akan dibuang dengan washing solution. Setelah itu ditambahkan ligan yang bertanda enzim, pada penelitian ini digunakan antimouse 
IgG yang membawa enzim alkaline fosfatase. Kemudian ditambahkan substrat kromogenik yaitu substrat 4-nitrophenol phosphatase, yang bila bereaksi dengan enzim dapat menimbulkan perubahan warna. Perubahan warna yang terjadi sesuai dengan jumlah enzim yang diikat dan sesuai pula dengan kadar antibodi yang dicari (Janeway et al., 2001).

Kadar antibodi poliklonal anti-ESA yang memiliki nilai paling tinggi akan digunakan untuk identifikasi protein rekombinan pada metode Western-blot. Hasil pembacaan ELISA menggunakan ELISA reader dengan panjang gelombang $405 \mathrm{~nm}$, menunjukkan nilai tertinggi 3,265 (Tabel 1 dan Gambar 1). Serum tersebut selanjutnya akan digunakan untuk mendeteksi reaktivitas imunogenisitas protein rekombinan.
Keuntungan menggunakan antibodi poliklonal ESA, dapat mengenali berbagai macam epitop antigen, sehingga dapat memperkuat signal penempelan bila protein yang diekspresikan sangat rendah. Hal ini disebabkan protein dapat mengikat lebih dari satu epitop, namun multiple epitop dapat memperkuat deteksi. Antibodi poliklonal lebih toleransi terhadap perubahan yang terjadi pada antigen (misal: polymorphism) serta dapat mengidentifikasi protein dengan homologi tinggi. Dampak buruknya dari penggunaan antibodi poliklonal, pada saat Western-blot akan menimbulkan background pita protein yang tidak spesifik dan dapat terjadi reaksi silang (Lipman et al., 2005).

Tabel Lampiran 1. Tabel titer serum antibodi poliklonal anti-ESA dengan metode ELISA pada OD450

\begin{tabular}{|c|c|c|c|c|c|c|c|c|c|c|c|c|}
\hline & 1 & 2 & 3 & 4 & 5 & 6 & 7 & 8 & 9 & 10 & 11 & 12 \\
\hline A & $* * * *$ & 3,168 & 2,715 & 3,122 & 3,214 & 2,178 & 2,204 & 2,686 & 0,192 & 1,027 & 0,028 & 0,033 \\
\hline B & $\mathbf{3 , 2 6 5}$ & 2,782 & 2,576 & 2,894 & 2,629 & 1,812 & 1,923 & 2,288 & 0,179 & 0,994 & 0,013 & 0,017 \\
\hline C & 2,995 & 2,497 & 2,339 & 2,507 & 2,441 & 1,686 & 1,689 & 2,026 & 0,173 & 1,013 & 0,005 & 0,011 \\
\hline D & 2,584 & 2,144 & 2,076 & 2,081 & 1,653 & 1,504 & 1,452 & 1,852 & 0,172 & 0,964 & 0,009 & 0,012 \\
\hline E & 2,157 & 1,980 & 1,951 & 1,785 & 1,456 & 1,280 & 1,304 & 1,483 & 0,174 & 0,928 & 0,006 & 0,012 \\
\hline F & 1,787 & 1,669 & 1,645 & 1,540 & 1,351 & 1,228 & 1,083 & 1,314 & 0,177 & 0,923 & 0,011 & 0,018 \\
\hline G & 1,563 & 1,438 & 1,375 & 1,368 & 1,154 & 1,193 & 1,056 & 1,145 & 0,178 & 0,870 & 0,019 & 0,022 \\
\hline H & 1,449 & 1,319 & 1,226 & 1,226 & 1,130 & 1,179 & 1,011 & 1,120 & 0,189 & 0,908 & 0,025 & 0,025 \\
\hline
\end{tabular}

Keterangan: ${ }^{1-8)}$ serum antibodi poliklonal anti ESA yang berasal dari mencit; ${ }^{9)}$ serum yang berasal dari mencit kontrol negative; ${ }^{10)}$ kontrol buffer (hanya diberi larutan buffer inkubasi); ${ }^{11)}$ kontrol konjugat (hanya diberi larutan konjugat); ${ }^{12)}$ well tidak diberi perlakuan; ${ }^{\mathrm{A}-\mathrm{H})}$ pengenceran; ${ }^{* * * *}$ ) data tidak terbaca

$$
\begin{aligned}
& \text { Optical density (OD) } 5 \times \text { pengenceran DNA takizoit T.gondii (5 } \\
& \mu 1 \text { DNA takizoit+ } 45 \mu 1 \text { akuabidest steril) } \\
& \mathrm{OD}_{260}=0,0650 \\
& \mathrm{OD}_{280}=0,0510 \\
& \text { Konsentrasi } 5 \times \text { DNA Takizoit } \\
& \begin{aligned}
= & 0.0650 \times 50 \times 50 \mu \mathrm{g} / \mathrm{ml}=162.5 \mu \mathrm{g} / \mathrm{ml}=162.5 \mathrm{ng} / \mu \mathrm{l} \\
& \text { Kemurnian }=0.0650 / 0.0510=1.27
\end{aligned}
\end{aligned}
$$

Gambar 1. Konsentrasi Antibodi Polikonal anti-ESA menggunakan spektrofotometer.

Imunogenik Protein Rekombinan (ROP-1) T.
gondii Isolat WTA
Reaktivitas imunogenik protein rekombinan ESA diuji tanding dengan antibodi poliklonal anti- 
ESA serum mencit, menggunakan metode Western-blot.

Pada Gambar 2 terlihat bahwa pada penelitian ini, dilakukan Western-blot untuk melihat reaksi antibodi poliklonal ESA terhadap ekspresi crude protein rekombinan ESA apakah epitop protein rekombinan dapat bereaksi atau dikenali oleh antibody poliklonal anti-ESA (Janeway et al., 2001). Pita yang terbentuk diperoleh hasil berbeda antara reaksi protein rekombinan ESA $T$. gondii dan $E$. coli BL21(D3) dengan antibodi poliklonal ESA pada membran nitroselulose. Hal ini memperlihatkan bahwa memang terjadi ikatan antar antibodi anti-ESA dengan protein rekombinan ESA $T$. gondii yang membentuk pita berukuran $97 \mathrm{kDa}$.

Terbentuknya pita yang lain kemungkinan disebabkan adanya ekspresi protein-protein lain yang terlibat dalam proses konformasi protein rekombinan atau protein-protein pengkotor yang berasal dari E. coli BL21(DE3) yang memiliki kemiripan epitop. Penggunaan antibodi poliklonal anti-ESA hasil imunisasi menggunakan protein ESA yang diisolasi dari takizoit $T$. gondii isolate WTA diketahui dilepaskan oleh tiga organela sekretoris apikal yaitu micronemes, rophtries dan dense granules (Joiner dan Ross, 2002)., kemungkinan didalamnya mengandung proteinprotein yang memiliki kemiripan homologi dengan protein rekombinan atau multiepitop ESA yang terkandung dalam antibody poliklonal anti-ESA mengenali multiepitop crude rekombinan protein rekombinan dan E. coli BL21(D3) (Carey et al., 2004).

Purifikasi diperlukan untuk memperoleh protein rekombinan murni bebas dari protein pengotor lainnya. Purifikasi protein rekombinan yang digunakan pada penelitian ini, apabila dipurifikasi menggunakan kromatografi affinitas, maka kemungkinan yang akan terikat pada kolom adalah protein fusi dengan berat molekul 20,4 kDa. Hal ini disebabkan protein His•Tag, dimana ligan ini berfungsi sebagai pengikat pada kolom, protein His•Tag akan berikatan dengan bahan insoluble misalnya nitrilotriacetate (NTA)-Ni2+-agarose. Fungsi lain dari His•Tag adalah untuk Western-blot menggunakan anti-His•Tag, sehingga diperoleh hasil bloting yang lebih sensitif dan spesifik (Sambrook and Russell,

2001)

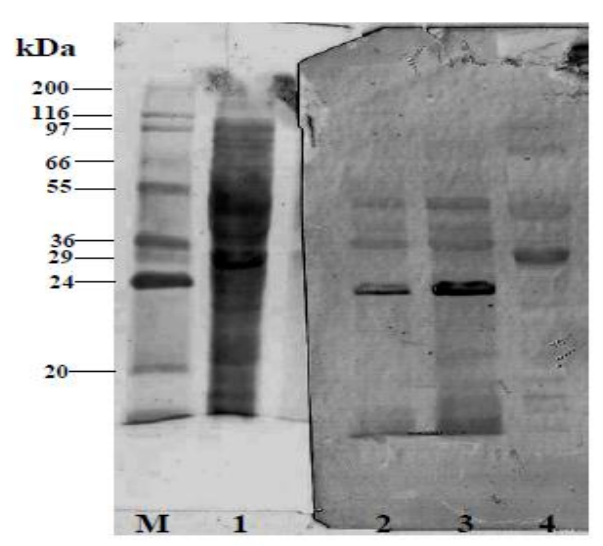

Gambar 2. Hasil analisis Western-blot Protein Rekombinan Dengan Antibody Poliklonal anti-ESA (Antibodi Mencit).

Keterangan: ${ }^{\mathrm{M})}$ marker protein; ${ }^{1,4)}$ protein rekombinan; ${ }^{2,3)}$ : protein kontrol (E. coli BL21(DE3) dan nonrekombinan $\mathrm{pET}-32 \mathrm{a}(+))$.

\section{SIMPULAN}

Protein rekombinan $97 \mathrm{kDa}$ excretory surface antigen (ESA) Toxoplasma gondii yang dihasilkan melalui teknik kloning dan diekspesikan pada $E$. coli BL21(D3) menunjukkan reaksi imunitas spesifik terhadap antibodi poliklonal anti-ESA.

\section{DAFTAR PUSTAKA}

Bivas-Benita, M., L. Marleen, V. Soetkin, D. Joelle, D. Brackeler, J. Eerik and B. Gerrit. 2003. Generation of Toxoplasma gondii GRA1 Protein and DNA Vaccine Loaded Chitosan
Paticles:Preparation, Characterization and Preliminary In Vivo Studies. Int. J. Pharm. 266: 17-27.

Black, M. W. and J. C. Boothrooyd. Lytic Cycle of Toxoplasma gondii. Proc. Natl. Acad. Sci. USA. 64 (3): 1092-2172.

Carruthers, V. 2004. Proteases as Potential Targets for Blocking Toxoplasma gondii Invasion dan Replication. In: Opportunistic Infection: Toxoplasma, Sarcocystic and Microsporidia. Kluwer Academic Publisher. Boston. 
Carey, K. L., N. J. Westwood, T. J. Mtchison and G. E. Ward. 2004. A Small-Molecule Approach to Studying Invasive Mechanism of Toxoplasma gondii. Proc. Natl. Acad. Sci. USA. 101 (19): 7433-7438.

Couper, K. N., H. V. Nielsen, E. Petersen, F. Roberts, C. W. Roberts and J.Alexanders. 2003. DNA Vaccination with The Immunodominant Tachyzoit Surface Antigen (SAG-1) Protects againts Adult Acquired Toxoplasma gondii Infection but does not Prevent Maternofoetal Transmission. Elsevier Scien. Direct. 21: 2813-2820.

Denkers, E. and R. T. Gazzinelli. 1998. Regulation and Function of T-Cell-Mediated Immunity during Toxoplasma gondii Infection. Clin.Microbiol. Rev. 11 (4): 569-588.

Dubey, J. P., D. S. Lindsay dan C. A. Speer. 1998. Structure of Toxoplasma gondii Tachyzoites, Bradyzoites and Sporozoites and Biology and Development of Tissues Cysts. Proc. Natl. Acad. Sci. USA. 11 (2): 267-299.

Janeway, C. A, Jr., P. Travers, M. Walport and M. J. Shlomchik. 2001. Immunobiology: The Immun System in Health and Disease. 5th edition. Garland Publishing. New York.

Joiner, K. A. and D. S. Ross. 2002. Secretory Traffic in the Eukaryotic Parasite Toxoplasma gondii: less is more. J. Cell. Biol. 157 (4): p. 557-563.

Lipman, N. S., L. R. Jackson, L. J. Trudel and F. Weis-Garcia. 2005.Monoclonal Versus Polyclonal Antibodies: Distinguishing, Characteristic, Application and Information Resourches. ILAR Journal. 46 (3): 258268.
Liu, K., D. Zhang, Q. Wei, J. Li, G. Li and J. Yu. 2006. Biological Rule of Surface Toxoplasma gondii Antigen in Development of Vaccine. World J. Gastroenterol. 12 (15): 2363-2368.

Pietkiewicz, H., E. Hiszczynska-Sawicka, J. Kur, E. Petersen, H. V. Nielsen, M. Paul, M. Stankiewicz and P. Miyjak. 2007. Usefulness of Toxoplasma gondii Recombinant Antigens (GRA1, GRA7 and SAG1) in an Immunoglobulin G Avidity Test for The Serodiagnosis of Toxoplasmosis. Parasitol. Res. 100: 333-337.

Roberts, C. W., R. T. Gazzinelli, I. A. Khan, A. E. D. Nowakowska and R. McLeod. 2007. Adaptive Immunity and Genetics of The Host Immun Response. In: Toxoplasma gondii the model Apicomplexan: Perspectives and methodes. Elsevier, Ltd. UK.

Sambrook, J. and D. W Russel. 2001. Molecular Cloning: A Laboratory Manual. 3rd edition. Cold Spring Harbour Laboratory Press. New York.

Schwartzman, J. D. 2001. Toxoplasmosis. In: Principles and Practice of Clinical Parasitology. John Wiley and Sons Ltd. USA.

Templeton, T. J. 2007. The Secretory Protein Repertoir and Expanded Gene Families of Toxoplasma gondii and Other Apicomplexa. In: Toxoplasma gondii the model Apicomplexan: Perspectives and methodes. Elsevier, Ltd. UK.

Wong, D. W. S. 2006. The ABCs of Gene Cloning. 2nd edition. Springer Science +Business Media, Inc. USA. 